\title{
Spherical and needle shaped magnetic nanoparticles for friction and magnetic stimulated transformation of microorganisms
}

\author{
G.P. Mendes ${ }^{\mathrm{a}, \mathrm{b}, \mathrm{e}, *}$, L.D. Kluskens ${ }^{\mathrm{a}, 1}$, M. Mota ${ }^{\mathrm{a}}$, S. Lanceros-Méndez ${ }^{\mathrm{b}, \mathrm{c}, \mathrm{d}}$, T. Alan Hatton ${ }^{\mathrm{e}}$ \\ ${ }^{a}$ Center of Biological Engineering, University of Minho, Campus de Gualtar, 4710-057 Braga, Portugal \\ ${ }^{\mathrm{b}}$ Center of Physics, University of Minho, Campus de Gualtar, 4710-057 Braga, Portugal

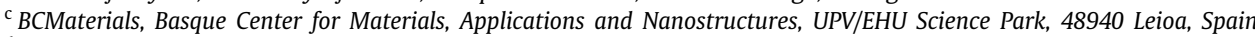 \\ ' IKERBASQUE, Basque Foundation for Science, 48009 Bilbao, Spain \\ e Department of Chemical Engineering, Massachusetts Institute of Technology, 77 Massachusetts Avenue, Cambridge, MA 02139, USA
}

\section{A R T I C L E I N F O}

Article history:

Received 2 March 2021

Received in revised form 24 March 2021

Accepted 26 March 2021

\section{Keywords:}

Escherichia coli

Magnetic nanoparticles

Magnetite

Magnetofection

Verwey transition

Yoshida effect

\begin{abstract}
A B S T R A C T
Spherical and needle shaped magnetic nanoparticles (MNPs) were synthesized by thermal decomposition, functionalized with 2-pyrrolidinone for the attachment of pUC19 plasmidic DNA and used in transformations assays of Escherichia coli JM109. Frictional and magnetic stimulation were employed for promoting the translocation of the nanoparticle-pUC19 complexes across the cell envelope. Transformants were obtained through frictional stimulation using needle shaped MNPs achieving a maximum transformation efficiency of $3.1 \times 10^{2} \mathrm{CFU} / \mu \mathrm{g}$ pUC19. Magnetic stimulation was also performed using both types of nanoparticles under conventional magnetofection conditions on a magnetic bioreactor and did not induce transformation of E. coli JM109, possibly due to the field intensity at the region of the cells $(\sim 100 \mathrm{mT})$ not being high enough to overcome the rigidity of the bacterial cell envelope. This work substantiates the need for the delivery agent to have a high aspect ratio in order to achieve transformation of prokaryotes. Moreover, it highlights the limitations of magnetic stimulation for translocation of MNPs across the microbial cell wall, as opposed to magnetofection of eukaryotic cells whereby the entry of genetic material can be readily accomplished using spherical MNPs through an endocytotic uptake mechanism.
\end{abstract}

(c) 2021 Elsevier B.V. All rights reserved.

\section{Introduction}

Transformation or genetic modification of microorganisms is predominantly performed by heat-shock or electroporation but many species remain recalcitrant to these methods, in particular anaerobes and species from the kingdom Archaea [1]. The search for alternative methodologies to deliver DNA into microorganisms to attain an intended genetic expression is a prominent task for the development of new pharmaceuticals and bio-fuels and for the production of endogenous compounds or enzymes for the chemical, food, environmental and related industries [2]. The use of MNPs to transfect mammalian cells through magnetofection is an approach that has been implemented over the past two decades [3]. It is a strategy used for delivering genetic material into the interior of cells through the action of an external magnetic stimulus applied to a magnetic delivery agent composed by a metallic nanoparticle core which is usually coated

\footnotetext{
* Corresponding author at: Center of Biological Engineering, University of Minho, Campus de Gualtar, 4710-057 Braga, Portugal.

E-mail address: gabriel.mendes@dep.uminho.pt (G.P. Mendes).

1 Dedicated to the memory of L.D. Kluskens.
}

with a DNA attachment agent such as polyethylenimine (PEI). However, magnetofection has not become a widespread strategy for transformation of microorganisms, probably due to the small dimensions of microorganisms as compared to eukaryotic cells, discouraging research directed towards the development of protocols that would require a corresponding size reduction of the magnetic delivery agent for cell-envelope permeation. Furthermore, microorganisms usually possess a rigid cell wall that is unfavorable for translocation of macromolecules from the cell exterior into the cytoplasm, and evidence suggests that the mechanism underlying magnetofection in eukaryotic cells is based on endocytosis [4-8], a process performed only by a few bacterial species $[9,10]$. On the other hand, frictional stimulation has been a method successfully used to genetically modify microorganisms using nanofibers such as sepiolite $[11,12]$ or nanosheets such as aminoclays $[13,14]$, that morphologically resemble nanoneedles and nanoblades respectively and are able to permeate microbial membranes when friction is applied. Nanomaterials with high aspect ratio is a highly researched topic since these nanomaterials have the potential to enable cell penetration and therefore are being explored for the development of materials with bactericidal activity that preclude the formation of biofilms in medical 
devices [15-17] or provide alternative solutions to conventional antibiotics for certain applications [18-20]. On the hand, delivery of genes into cells for medical or biotechnology purposes is a prominent and well-established topic where various types of nanoparticles can be employed as delivery agents. Nanoparticles such as sepiolite or $\mathrm{Mg}$ aminoclays have been used as delivery agents of genetic material for microorganisms due to their ability to translocate the cell envelope, reversibly attach DNA and release it in a fully functional state inside the cell. Nevertheless, the influence of the aspect ratio of the delivery agent in the promotion of DNA delivery into cells is still poorly understood and further examination is required for a proper description of the translocation mechanism that leads to genetic modification by this approach. Furthermore, the synthesis and characterization of nanoparticles with shape anisotropy is also very relevant for the development of other fields such as nanofluids [21,22], thermal engineering [23,24] magnetic resonance imaging [25,26], drug delivery $[27,28]$ and hyperthermia therapy $[29,30]$, among others.

In fact, magneto-transformation has already been achieved on Escherichia coli DH1 by Chen et al. using a pulsed magnetic field of $2.15 \mathrm{~T}$, but the highest transformation efficiency obtained with an acceptable cell survival rate (1.1\%) using PEIcoated MNPs with an overall average size of $65 \mathrm{~nm}$ was only 64 $\mathrm{CFU} / \mu \mathrm{g}$ DNA [31]. Transformation of microorganisms using delivery agents or nanocarriers has been mainly performed through the employment of acicular material such as sepiolite [32-35] or chrisolite [36-40] due to their ability in promoting DNA entry into cells following cell piercing. Needle shaped natural materials have shown large potential for transformation of a small variety of microorganisms such as Escherichia coli strains DH5 $\alpha$ and C600 [41], TOP 10 [33], JM109 [34,36-39] and XL-2 Blue [11], Agrobacterium radiobacter IFO2665b1 and Thiobacillus intermedius 131 [40], Yersinia enterocolitica WA-314 and Acinetobacter baumannii ATCC17978 [33], Pseudomonas aeruginosa strains PA01, PA14, ATCC27853 and PA JCI-1A7 and Pseudomonas putida KT2440 [32] and Salmonella Typhimurium LT2 [35].

In this work, synthetic needle shaped MNPs functionalized with 2-pyrrolidinone were produced and their potential for transforming non-competent E. coli JM109 using magnetic and frictional stimulation was evaluated. The transformation potential of sub ten-nanometer diameter 2-pyrrolidinone coated spherical shaped MNPs was also tested under the same conditions. The coating agent was selected to promote hydrophilicity of the assynthesized MNPs and affinity for plasmids without substantial gain in diameter, as 2-pyrrolidinone is known to exhibit cationic properties under a large $\mathrm{pH}$ range and a much smaller size than more conventional DNA attachment agents such as PEI.

\section{Materials and methods}

\subsection{Synthesis of 2-pyrrolidinone coated spherical MNPs}

The synthesis of 2-pyrrolidinone coated spherical MNPs was performed following the main guidelines of the method presented in Li et al. [42]. Four mmol $\mathrm{Fe}(\mathrm{acac})_{3}$ were mixed with $40 \mathrm{~mL}$ of 2-pyrrolidinone, stirred at $400 \mathrm{rpm}$ using a bar magnet under $\mathrm{N}_{2}$ flow to remove oxygen, and then heated to $200{ }^{\circ} \mathrm{C}$. The mixture was maintained at this temperature for $30 \mathrm{~min}$, heated to reflux $\left(249^{\circ} \mathrm{C}\right)$ and left at this temperature for another $15 \mathrm{~min}$. The flask was left cooling to room temperature and the content was divided in two centrifuge tubes ( $20 \mathrm{~mL}$ in each). Each 20 $\mathrm{mL}$ of MNPs dispersions was washed by adding $25 \mathrm{~mL}$ methanol, resulting in the formation of a dark precipitate. After centrifugation at $8421 \mathrm{~g}$ the pellet was suspended in $45 \mathrm{~mL}$ acetone using a vortex. A homogeneous dark dispersion was formed and another centrifugation step at $8421 \mathrm{~g}$ was performed, forming a clear supernatant which was discarded. After the addition of $45 \mathrm{~mL}$ acetone and vortexing, the centrifugation step was repeated and, after decanting, the content of each falcon was resuspended in 10 $\mathrm{mL}$ acetone and transferred to a scintillation glass vial. A strong permanent magnet was used to separate the nanoparticles from the acetone and the supernatant decanted. Ten $\mathrm{mL}$ acetone were added repeatedly to perform 3 more washes using the permanent magnet to remove the functionalized MNPs from all unbound 2pyrrolidinone. After the last decantation, the MNPs were finally left to dry in vacuum oven at $60{ }^{\circ} \mathrm{C}$ overnight, resulting in about $150 \mathrm{mg}$ of dried spherical MNPs product. All chemicals were purchased from Sigma Aldrich and used as provided.

\subsection{Synthesis of needle shaped MNPs and functionalization with 2-pyrrolidinone}

The synthesis of needle shaped MNPs was performed following the main guidelines of the method presented in Sun et al. [43]. Hexadecylamine $(0,20 \mathrm{~g})$, oleic acid $90 \%(2.6 \mathrm{~mL})$ and n-butanol $(8 \mathrm{~mL})$ were heated at $50{ }^{\circ} \mathrm{C}$ and magnetically stirred until a homogeneous solution was obtained. After cooling to room temperature, $2 \mathrm{~mL} \mathrm{Fe}(\mathrm{CO})_{5}>99.99 \%$ metal trace basis was then added using a syringe and stirred magnetically until dissolved. The liquid was transferred to a stainless-steel autoclave with a Teflon inner lining and left for $6 \mathrm{~h}$ at $200{ }^{\circ} \mathrm{C}$. After cooling to room temperature, the precipitate was centrifuged at $8421 \mathrm{~g}$, washed 3 times with ethanol and left to dry under ambient conditions. For functionalization of the needle shaped MNPs with a hydrophilic and DNA-affinity coating, a ligand-exchange of the oleic acid coating agent with 2-pyrrolidinone was performed. First, a sample consisting of $250 \mathrm{mg}$ of the previously obtained needle shaped MNPs was dispersed in a 50/50 mixture of 1,2dichlorobenzene and $\mathrm{N}, \mathrm{N}^{\prime}$-dimethylformamide $(30 \mathrm{~mL}$ of total volume), to which $5 \mathrm{~mL}$ of excess 2-pyrrolidinone was added. The mixture was then stirred at $100^{\circ} \mathrm{C}$ for $\sim 24 \mathrm{~h}$ under a reflux system. The needle shaped MNPs were subsequently precipitated by the addition of ethyl ether $(\sim 50 \mathrm{~mL})$ and recovered with a permanent magnet. The needle shaped MNPs were dispersed in acetone and precipitated by means of a permanent magnet 3 to 4 times to remove all traces of unbound coating agent. The samples were dried at ambient temperature for 2 days and sealed in a glass vial. Two hundred $\mathrm{mg}$ of 2-pyrrolidinone coated needle shaped MNPs were recovered using this procedure. The functionalization protocol followed the procedure presented in Lattuada et al. [44] for the functionalization of magnetite MNPs with citric acid. All chemicals were purchased from Sigma Aldrich and were of analytical grade, except for oleic acid, which was of technical grade.

\subsection{Transmission Electron Microscopy Measurements}

Transmission Electron Microscopy (TEM) measurements were performed on a JEOL 200CX (200 kV) microscope. All samples were prepared by evaporation of dilute dispersions in acetone on a carbon-coated film. ImageJ software was used to estimate the size distribution of the nanoparticles present in the samples by measuring at least 177 nanoparticles.

\subsection{Attenuated Total Reflectance Fourier Transform Infrared Spec- troscopy}

Attenuated Total Reflectance Fourier Transform Infrared (ATRFTIR) spectroscopy was performed on a Thermoscientific NEXUS 8700 FTIR spectrometer (Thermo Nicolet, Inc.). Spectra were recorded between 4000 and $500 \mathrm{~cm}^{-1}$ at a resolution of $2 \mathrm{~cm}^{-1}$ and are reported as the average of 64 spectral scans. All samples were previously dried under vacuum to evaporate any remaining solvent or moisture. 


\subsection{Superconducting Quantum Interference Device measurements}

Superconducting Quantum Interference Device (SQUID) measurements were conducted on both types of 2-pyrrolidinone coated MNPs using a Magnetic Property Measurement System model MPMS-XL (Quantum Design) to determine their magnetization. The hysteresis loop SQUID measurements were performed at $300 \mathrm{~K}$ and $10 \mathrm{~K}$ over $\mathrm{a}-10$ to $10 \mathrm{kOe}$ range and Zero Field Cooled-Field Cooled (ZFC-FC) measurements were performed from $1.8 \mathrm{~K}$ to $300.4 \mathrm{~K}$ under the influence of 100 Oe on samples weighing $7.5 \mathrm{mg}$. The ZFC measurements were performed by cooling the samples in a zero field from the upper temperature limit, which is well above the usual blocking temperature $\left(T_{B}\right)$ of magnetite MNPs (superparamagnetic state), down to the lower temperature limit, well below their usual $\mathrm{T}_{\mathrm{B}}$ (ferrimagnetic state). The magnetic field was then applied and the magnetization as a function of temperature was measured during the heating process back to the upper temperature limit. The FC curve was obtained by measuring the magnetization when cooling the sample back to the lower temperature limit in the same field as used during the heating period. The field used in the ZFC-FC measurements was weak enough in comparison with the anisotropy field to guarantee that the ZFC-FC curve reflected the intrinsic energy barrier distribution.

\subsection{Transformation assays}

\subsubsection{Transformation by frictional stimulation}

Agar containing Petri dishes were prepared using 2\% agar $2 \%$ lysogeny broth (LB) in $400 \mathrm{~mL}$ double distilled water that was autoclaved for $45 \mathrm{~min}$. In a sterile laminar flow hood, after the $2 \%$ agar $2 \%$ LB cooled to around $40{ }^{\circ} \mathrm{C}$, isopropyl $\beta$-D-1thiogalactopyranoside (IPTG), 5 -bromo-4-chloro-3-indolyl- $\beta$-Dgalactopyranoside (X-gal) and ampicillin were added to a final concentration of $1 \mathrm{mM}$ IPTG, $40 \mu \mathrm{g} / \mathrm{mL}$ X-gal and $100 \mu \mathrm{g} / \mathrm{mL}$ ampicillin. The mixture was divided into Petri dishes $(15 \mathrm{~mL}$ in each) and left to cool at room temperature. E. coli JM109 was grown overnight until an $\mathrm{OD}_{600}$ of 0.7 was reached. Then a 1:50 dilution was performed in LB and cells were left to grow until $\mathrm{OD}_{600}$ reached 1.2. Eight $1.5 \mathrm{~mL}$ Eppendorf tubes containing $500 \mu \mathrm{L}$ of cells each were centrifuged at $16162 \mathrm{~g}$ on a bench top centrifuge and the supernatant was decanted. Two separate stock dispersions of 2-pyrrolidinone coated spherical and needle shaped MNPs were prepared at $3 \mathrm{mg} / \mathrm{mL}$ in LB and sonicated for 15 min. After washing 3 times with LB with decantationcentrifugation steps, $1: 5,1: 10,1: 100$ and $1: 1000$ dilutions of these 2 separate nanoparticle dispersions were prepared in 2\% LB producing 2 sets of 4 samples having a concentration of $0.6,0.3$, 0.03 and $0.003 \mathrm{mg} / \mathrm{mL}$. Five $\mu \mathrm{L} 50 \mathrm{ng} / \mathrm{mL}$ of pUC19 were then added to $500 \mu \mathrm{L}$ of each of the previous samples and mixed with a micro-pipette using up and down movements, promoting nanoparticle-pUC19 complex formation. The cells were resuspended with $500 \mu \mathrm{L}$ of each of the previous mixtures. The resuspension was performed by vortexing $1 \mathrm{~min}$ and $100 \mu \mathrm{L}$ of each vial was plated inside a sterile laminar flow hood on previously prepared Petri dishes that were dried for at least 20 min. The spreading was performed with an L-shaped polystyrene spreader through about 50 circular spreading movements for $30 \mathrm{~s}$. The Petri dishes were left overnight in a bacteriological incubator (JP Selecta, model Incubat) at $37{ }^{\circ} \mathrm{C}$ to promote growth of the transformed colonies. Five replicas were produced for each concentration of MNPs and the highest and lowest numbers of colony forming units were discarded to diminish standard deviation, so the values presented are in triplicate. The colonies were counted using an automatic cell counter from Interscience (Scan 300) and the efficiency of transformation determined as colony forming units (CFU) per $\mu \mathrm{g}$ pUC19.

\subsubsection{Transformation by magnetic stimulation}

Transformation assays using an external magnetic field were performed using 6-well culture plates containing $1 \mathrm{~mL}$ of gel on each well that consisted of agar $2 \%$, LB $2 \%, 100 \mu \mathrm{g} / \mathrm{mL}$ ampicillin, $1 \mathrm{mM}$ IPTG and $40 \mu \mathrm{g} / \mathrm{mL}$ X-gal. E. coli JM109 suspensions and dispersions of MNPs were prepared using the same steps as in the frictional stimulation assays. The cells were grown overnight until an $\mathrm{OD}_{600}$ of 0.7 was reached. Then a 1:50 dilution was performed in $\mathrm{LB}$ and cells were left to grow until $\mathrm{OD}_{600}$ reached 1.2. For each concentration of MNPs used, one $1.5 \mathrm{~mL}$ Eppendorf tube containing $500 \mu \mathrm{L}$ of cells was centrifuged at $16162 \mathrm{~g}$ on a bench top centrifuge and the supernatant was decanted. A stock dispersion of 2-pyrrolidinone coated spherical shaped MNPs were prepared at $3 \mathrm{mg} / \mathrm{mL}$ in LB and sonicated for $15 \mathrm{~min}$. After washing 3 times with LB with decantation-centrifugation steps, a 1:5 dilution was prepared in $2 \% \mathrm{LB}$ producing a sample having a concentration of $0.6 \mathrm{mg} / \mathrm{mL}$. Five $\mu \mathrm{L} 50 \mathrm{ng} / \mathrm{mL}$ of pUC19 were then added to $500 \mathrm{~mL}$ of the previous sample and mixed with a micro-pipette using up and down movements, promoting nanoparticle-pUC19 complex formation, which was then used for resuspension of the E. coli JM109 cells in the pellet prepared previously. The resuspension was performed by vortexing the vial during $1 \mathrm{~min}$. Five replicas having $100 \mu \mathrm{L}$ each were added to 5 wells of a the 6-well culture plate containing $1 \mathrm{~mL}$ of agar/LB $2 \%, 100 \mu \mathrm{g} / \mathrm{mL}$ ampicillin, $1 \mathrm{mM}$ IPTG and $40 \mu \mathrm{g} / \mathrm{mL}$ X-gal that was dried for at least $20 \mathrm{~min}$. The culture plate was assembled on a MagnefectNano II $^{\mathrm{TM}}$ device (NanoTherics, UK). This bioreactor produces a oscillating magnetic field of approximately $100 \mathrm{mT}$ at the level of the cells [45,46] and was set to an oscillation frequency of $2 \mathrm{~Hz}$, displacement amplitude of $0.2 \mathrm{~mm}$ and kept working inside a bacteriological incubator (JP Selecta, model Incubat) at $37{ }^{\circ} \mathrm{C}$ for $72 \mathrm{~h}$. The same procedure was repeated using $0.3,0.03$ and 0.003 $\mathrm{mg} / \mathrm{mL}$ spherical shaped MNPs and the whole assay repeated using needle shaped MNPs under the same conditions.

\subsection{Statistical analysis}

The size distribution of the nanoparticles obtained using ImageJ software was analyzed using OriginPro software to determine the mean values, standard deviations and to fit a lognormal curve to the obtained histograms. To assess statistical differences among the number of colonies among different samples, a one-way ANOVA test was used. For determination of differences between means, a Tukey HDS test was performed as required. Differences were considered significant for $\mathrm{P}$ values $\leq 0.05$. ${ }^{*}=$ $0.05 \geq \mathrm{P}>0.01 ;{ }^{* *}=0.01 \geq \mathrm{P}>0.001 ;{ }^{* * *}=\mathrm{P} \leq 0.001$. All tests were performed using Graphpad Prism analysis software package.

\section{Results and discussion}

\subsection{Nanoparticle synthesis, functionalization and characterization}

The production of 2-pyrrolidinone coated spherical MNPs was accomplished by the simultaneous employment of 2-pyrrolidinone as solvent and coating agent. The spherical MNPs were synthesized by a direct route where the $\mathrm{Fe}(\mathrm{acac})_{3}$ precursor is thermally decomposed in strong polar 2-pyrrolidinone stabilizer while heated under reflux. These nanoparticles do not need to be submitted to any further treatment for becoming dispersible in water, since the 2-pyrrolidinone coating layer ensures hydrophilicity. The size distribution of these nanoparticles was measured using Image software, and the mean diameter obtained was $6.1 \pm 2.0 \mathrm{~nm}(\mathrm{~N}=177)$ (Fig. 1a). On the other hand, the reaction responsible for the formation of needle shaped MNPs proceeds through a solvothermal reaction controlled by a side reaction in which initially part of the $\mathrm{Fe}(\mathrm{CO})_{5}$ precursor 

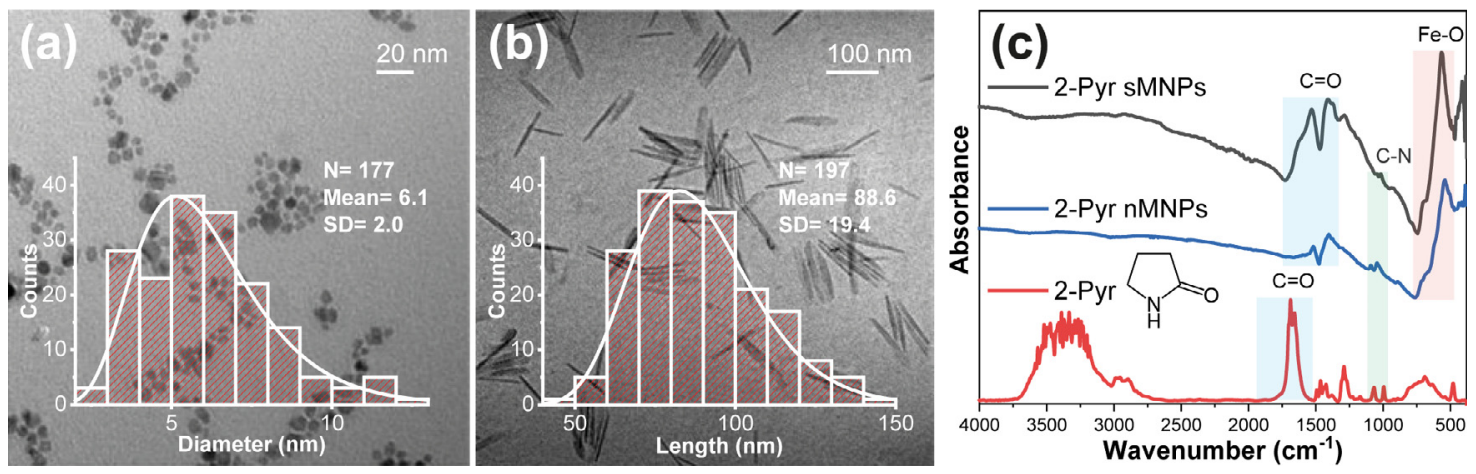

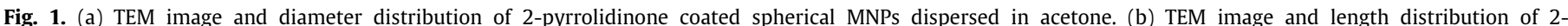

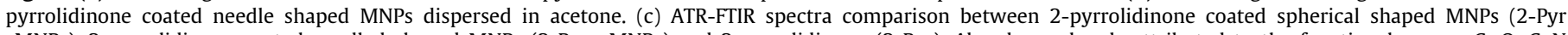

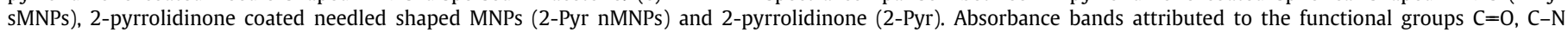
and $\mathrm{Fe}-\mathrm{O}$ are highlighted.

decomposes to form the oxidized form $\mathrm{FeO}$ while some reacts with oleic acid to form iron oleate. Oleic acid also reacts with hexadecylamine that is present in the mixture producing water which in turn hydrolyzes iron oleate forming the initial needle shaped MNPs of $\mathrm{Fe}_{3} \mathrm{O}_{4}$. Subsequently, the dissolution of $\mathrm{FeO}$ and decomposition of residual $\mathrm{Fe}(\mathrm{CO})_{5}$ as well as the hydrolysis of iron oleate provides a source for the growth of these $\mathrm{Fe}_{3} \mathrm{O}_{4}$ MNPs and their enlargement over time. By adjustment of the amount of oleic acid added, the size and dispersity of the needle shaped MNPs were finely tuned (Fig. S1). The hydrophilicity of these MNPs was promoted through ligand exchange of the coating agent oleic acid by 2-pyrrolidinone, and the size distribution of the 2-pyrrolidinone coated needle shaped MNPs produced using $2.6 \mathrm{~mL}$ oleic acid was analyzed through Image software. The mean values obtained for their length and width were $88.6 \pm 19.4 \mathrm{~nm}$ and $8.4 \pm 2.3 \mathrm{~nm}$ respectively $(\mathrm{N}=197)$ (Fig. 1b and Fig. S2). Both types of nanoparticles are dispersible in acetone and water and no additional procedure is necessary to ensure DNA affinity [47]. Considering the X-ray diffraction and X-ray photoelectron analysis presented in Li et al. [42] and Sun et al. [43], both types of MNPs are expected to be composed of $\mathrm{Fe}_{3} \mathrm{O}_{4}$ and the coordination of 2-pyrrolidinone to their surface to occur through the carbonyl group of 2-pyrrolidinone.

ATR-FTIR spectroscopy was performed to determine whether the 2-pyrrolidinone ligand was attached to the nanoparticle surface through its carbonyl oxygen or nitrogen (Fig. 1c). The carbonyl $(\mathrm{C}=\mathrm{O})$ absorbance of 2-pyrrolidinone is known to undergo a shift to lower wavenumbers when its oxygen is covalently or hydrogen bonded to the metal atoms from the surface of the nanoparticle [48]. As highlighted in Fig. 1c, the absorbance band due to the stretch of the carbonyl group of pure 2-pyrrolidinone lays on the $1516-1913 \mathrm{~cm}^{-1}$ region and shifts to the $1331-1728 \mathrm{~cm}^{-1}$ region when bound to iron oxide. This shift of $185 \mathrm{~cm}^{-1}$ indicates that the 2-pyrrolidinone coating agent coordinates on the surface of the MNPs through the carbonyl oxygen of the ligand binding to a surface metal atom, which is in agreement with the results obtained by Kinsella et al. [49]. Moreover, the band corresponding to the $\mathrm{C}-\mathrm{N}$ stretch remains unaltered at $970-1116 \mathrm{~cm}^{-1}$ among all samples, indicating that the nitrogen does not coordinate to the surface of the MNPs. The appearance of a new band containing peaks at 567 and $690 \mathrm{~cm}^{-1}$ exclusive to both samples of coated MNPs is due to the presence of an iron-oxygen ( $\mathrm{Fe}-\mathrm{O}$ ) bond, which constitutes a confirmation that the synthesized nanoparticles are composed of iron oxide [50].

\subsection{Magnetic properties}

Relevant information can be retrieved from the magnetic properties of a material by studying its magnetization curve or hysteresis loop [51] (Fig. 2). The non-magnetic coating layer composed of 2-pyrrolidinone contributes to the mass of the MNPs and therefore influences the saturation magnetization $\left(M_{S}\right)$, which is obtained by dividing the maximum magnetization achieved in each sample by the corresponding mass. The 2-pyrrolidinone coated spherical MNPs exhibit superparamagnetic properties at room temperature since no significant hysteresis is observable [52] (Fig. 2a), which means that the thermal energy can overcome the anisotropy energy barrier of a single particle and that the net magnetization of particle assemblies is zero in the absence of an external field. The obtained $\mathrm{M}_{\mathrm{s}}$ is approximately $49 \mathrm{emu} / \mathrm{g}$. The difference in $M_{s}$ compared to bulk magnetite (up to $92 \mathrm{emu} / \mathrm{g}$ for commercialized fine powder) is attributed to the small size of the particles and the difference in magnetization compared to MNPs of similar size synthesized by other methods, might be due to surface spin canting effects since polar 2-pyrrolidinone was used instead of oleic acid. For example, in the case of the production of $6.0 \mathrm{~nm}$ oleic acid coated MNPs by hot injection of precursors composed of iron pivalate clusters in mixtures of dodecanol/oleic acid/hexadecanol, a $\mathrm{M}_{\mathrm{s}}=62 \mathrm{emu} / \mathrm{g}$ at $300 \mathrm{~K}$ was observed [53]. The obtained value of $\mathrm{M}_{\mathrm{s}}=49 \mathrm{emu} / \mathrm{g}$ fits well between the values 31 and $65 \mathrm{emu} / \mathrm{g}$ reported by $\mathrm{Li}$ et al. for the production 2-pyrrolidinone coated MNPs of diameter 5 and $8 \mathrm{~nm}$ respectively [42]. On the hand, at $10 \mathrm{~K}$, the spherical shaped MNPs exhibited hysteresis, presenting ferrimagnetic behavior with a coercivity of approximately 246 Oe, which is consistent with other works, such as the findings reported by Phong et al. [54].

The magnetization curve for needle shaped MNPs at $300 \mathrm{~K}$ (Fig. 2b) exhibited hysteresis and a slight remanent magnetization in the absence of external field $\left(\mathrm{M}_{\mathrm{r}}=3.84\right)$, which means that these MNPs are not superparamagnetic at room temperature. The $\mathrm{M}_{\mathrm{s}}$ obtained at $300 \mathrm{~K}$ is approximately $30 \mathrm{emu} / \mathrm{g}$, which is superior to the value reported by Sun et al. (20 emu/g) [43], but the exact nanorod length that was used in this report for obtaining the presented $M_{s}$ value is not clear, lying between 28 and $140 \mathrm{~nm}$. The $M_{s}$ should be proportional to the size of the particles, but the high shape anisotropy of the needle shaped MNPs prevents the magnetization in directions other than along their easy magnetic axes $[55,56]$, which is responsible for the observed low $\mathrm{M}_{\mathrm{s}}$ obtained from the 2-pyrrolidinone coated needle shaped MNPs in comparison to the spherical shaped ones. For attaining genetic modification by simultaneous spreading of $E$. coli/plasmid/MNPs, some agglomeration should be produced due to the remanent magnetization, but transformation of microorganisms should still 


\section{2-Pyr spherical MNPs}

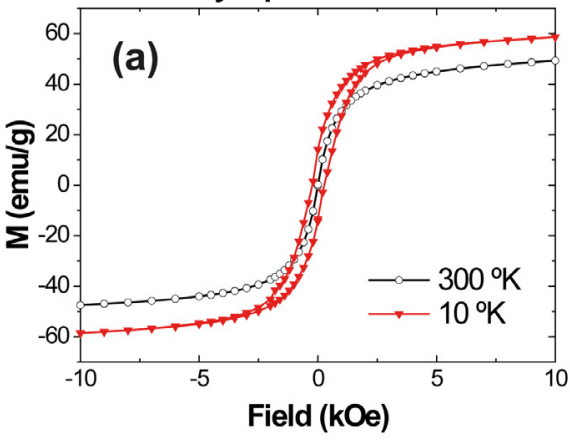

2-Pyr spherical MNPs

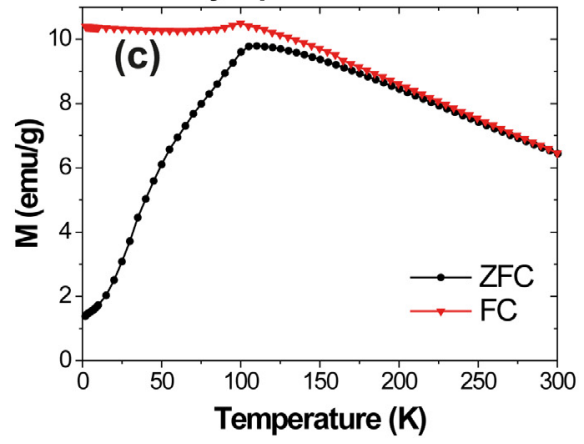

2-Pyr needle MNPs

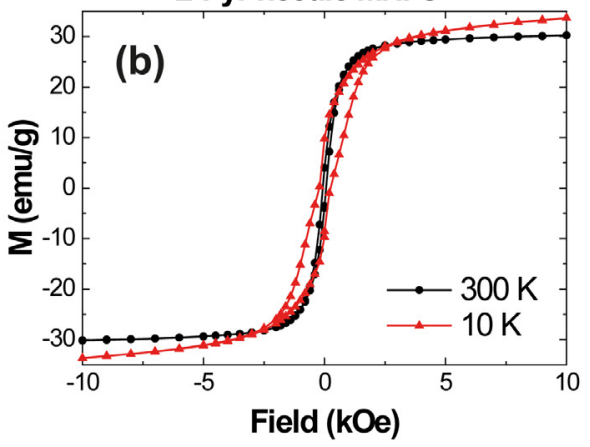

2-Pyr needle MNPs

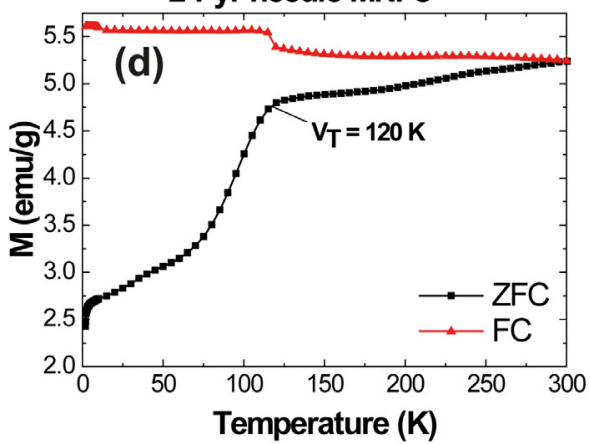

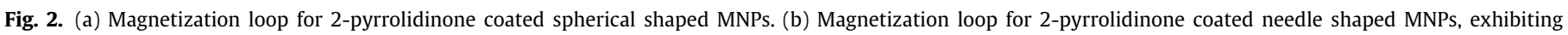

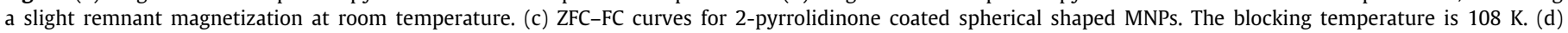
ZFC-FC measurement for 2-pyrrolidinone coated needle shaped MNPs. ZFC-FC measurements were performed from $1.8 \mathrm{~K}$ to $300.4 \mathrm{~K}$ under a field of 100 Oe.

be possible, since it has been acknowledged that transformation by frictional stimulation of nanofibers is achieved by the formation of chestnut bur-shaped aggregates [37]. The employment of friction combined with the ferrimagnetic nature of the synthetic needle shaped MNPs presented in this work should also promote the formation of bur-shaped aggregates and therefore favor the transformation process. A summary of the relevant magnetic properties is summarized in Table 1.

The temperature-dependent magnetization data measured in zero-field-cooled (ZFC) and field-cooled (FC) are usually used to obtain information about energy barriers, but additional information can be inferred through the analysis of these plots (Fig. 2c and Fig. 2d). As depicted in Fig. 2c, when the temperature is increased from $1.8 \mathrm{~K}$ to $300.4 \mathrm{~K}$ the ZFC first increases and then decreases after reaching a maximum at $108 \mathrm{~K}$, which corresponds to the blocking temperature $\mathrm{T}_{\mathrm{B}}$. This result further proves that the 2-pyrrolidinone coated spherical shaped MNPs are superparamagnetic at room temperature. The FC magnetization continues to decrease as the temperature is increased and the difference in magnetization between the ZFC magnetization and FC magnetization below $T_{B}$ is attributed to energy barriers of the magnetization anisotropy.

The magnetization anisotropy constant $\mathrm{K}_{\mathrm{an}}$ can be calculated by the following formula:

$\mathrm{K}_{\mathrm{an}}=25 \mathrm{k}_{\mathrm{b}} \mathrm{T}_{\mathrm{B}} \mathrm{V}^{-1}$

where $K_{b}$ is the Boltzmann constant, $T_{B}$ is the blocking temperature of the sample and $\mathrm{V}$ is the volume of a single particle [57]. The estimated magnetic anisotropy constant $K_{a n}$ for the 2-pyrrolidinone coated spherical shaped MNPs is $4.18 \times 10^{5} \mathrm{~J} / \mathrm{m}^{3}$, when a radius of $6.1 \mathrm{~nm}$ and $\mathrm{a}_{B}$ of $108 \mathrm{~K}$ is assumed. This value is of the same order of magnitude as those obtained by Li et al. for 4.5 and $8.5 \mathrm{~nm}$ trithiol-terminated poly(methacrylic acid) coated MNPs $\left(1.81 \times 10^{5}\right.$ and $\left.1.02 \times 10^{5} \mathrm{~J} / \mathrm{m}^{3}\right)$ for $\mathrm{a} \mathrm{T}_{\mathrm{B}}$ of $25 \mathrm{~K}$ and 85 $\mathrm{K}$ respectively [58].
Magnetite has a cubic spinel structure of $\mathrm{AB}_{2} \mathrm{O}_{4}$ type (space group $\mathrm{Fd} 3 \mathrm{~m}$ ), that contains $\mathrm{Fe}^{3+}$ ions at tetrahedral sites (A) and $\mathrm{Fe}^{3+} / \mathrm{Fe}^{2+}$ at octahedral sites (B) [59]. At low temperature, the system undergoes a structural conversion, which is responsible for a metal-insulator transition (also known as the Verwey transition $\left(\mathrm{V}_{\mathrm{T}}\right)$ (Fig. 2d)), and concurrently the magnetic, calorimetric, electric and optical conductivity undergo a sudden change at this temperature $[60,61]$. This transition temperature is shifted to lower values in smaller particles [62] but is very sensitive to oxygen stoichiometry, which disfavors a straightforward sizedependent characterization due to the variety of particle growth conditions that are reported. However, the Verwey transition is usually suppressed when particles have a diameter below $20 \mathrm{~nm}$, and completely disappears for sizes below $6 \mathrm{~nm}$ [63,64]. For the needle shaped MNPs obtained in this work with estimated length of $88.6 \pm 19.4 \mathrm{~nm}$ and width of $8.4 \pm 2.3$, a slight kink in the ZFC curve at around $120 \mathrm{~K}$ emerges, which coincides with the $\mathrm{V}_{\mathrm{T}}$ transition of $\mathrm{Fe}_{3} \mathrm{O}_{4}$ [65]. Such a signature of the Verwey transition in $\mathrm{Fe}_{3} \mathrm{O}_{4}$ MNPs is not uncommon and has been reported before in other literature pertaining to $\mathrm{Fe}_{3} \mathrm{O}_{4}$ MNPs with needle-like shape [66,67]. The Verwey transition is a special characteristic of magnetite, which confirms that the needle shaped MNPs samples contain $\mathrm{Fe}_{3} \mathrm{O}_{4}$ in their composition. When cooled below the characteristic Verwey transition at $\mathrm{V}_{\mathrm{T}} \sim 120 \mathrm{~K}$, the electrical conductivity of $\mathrm{Fe}_{3} \mathrm{O}_{4}$ abruptly drops by two orders of magnitude and is accompanied by a slight crystallographic distortion [68]. Other studies on magnetite MNPs suggest that the Verwey transition shifts to lower temperatures due to the finite-size effect, or as mentioned above, vanishes below a critical size [69], not being detected in the ZFC-FC measurements of 2-pyrrolidinone coated spherical MNPs presented in this work. 
Table 1

Magnetic properties of both types of 2-pyrolidinone coated MNPs at 300 and $10 \mathrm{~K}$ used in transformation assays. Values were obtained from the magnetization loop curves scanned at variable field. $\mathrm{M}_{\mathrm{s}}-$ Saturation magnetization; $\mathrm{H}_{\mathrm{C}}$ - Coercivity; $\mathrm{M}_{\mathrm{r}}$ - Remanent magnetization.

\begin{tabular}{llllll}
\hline 2-Pyrrolidinone coated MNPs & $\mathrm{T}(\mathrm{K})$ & $\mathrm{M}_{\mathrm{s}}(\mathrm{emu} / \mathrm{g})$ & $\mathrm{H}_{\mathrm{c}}(\mathrm{Oe})$ & $\mathrm{M}_{\mathrm{r}}(\mathrm{emu} / \mathrm{g})$ & $\mathrm{R}=\mathrm{M}_{\mathrm{r}} / \mathrm{M}_{\mathrm{s}}$ \\
\hline Spherical shaped & 300.00 & 49.09 & 2.09 & 0.21 & 0.00 \\
& 10.00 & 58.60 & 246.60 & 13.92 & 0.24 \\
\hline Needle shaped & 300.00 & 30.19 & 69.26 & 3.84 & 0.13 \\
& 10.00 & 33.67 & 235.97 & 9.34 & 0.28 \\
\hline
\end{tabular}

\subsection{Transformation assays}

\subsubsection{Transformation of E. coli JM109 with pUC19 using frictional stimulation}

Escherichia coli JM109 is a popular host in recombinant DNA technology especially for cloning and plasmid expression purposes and was selected in this work as a model for transformation assays with both types of MNPs due to its versatility, robustness and widespread use. The plain pUC19 plasmid without any DNA insertion in its multiple cloning site was used as a proof-ofconcept for transformation accomplishment. Therefore, cell survival at the employed ampicillin concentration is a good indicator of transformation since this plasmid grants ampicillin resistance after being correctly translated by the host cell. Moreover, when the cells are plated on a medium supplemented with IPTG and Xgal, transformed colonies are expected to grow in blue instead of white color due to $\alpha$-complementation of the $\omega$-peptide fragment (mutant $\beta$-galactosidase from E. coli JM109) with the $\alpha$-peptide fragment (encoded by the lacZ $\alpha$ sequence from pUC19), which confirms the occurrence of an induced genetic modification.

The transformation assays using frictional stimulation only produced transformants when 2-pyrrolidinone coated needle shaped MNPs were used (Fig. 3a). The average transformation efficiency obtained was $2.9 \times 10^{2} \mathrm{CFU} / \mu \mathrm{g}$ pUC19 for $0.6 \mathrm{mg} / \mathrm{mL}$, $3.1 \times 10^{2} \mathrm{CFU} / \mu \mathrm{g}$ pUC19 for $0.3 \mathrm{mg} / \mathrm{mL}, 9.3 \times 10^{1} \mathrm{CFU} / \mu \mathrm{g}$ pUC19 for $0.03 \mathrm{mg} / \mathrm{mL}$ and $3.3 \times 10^{1} \mathrm{CFU} / \mu \mathrm{g}$ pUC19 for 0.003 $\mathrm{mg} / \mathrm{mL}$. The maximum average transformation efficiency using needle shaped MNPs is $3.1 \times 10^{2} \mathrm{CFU} / \mu \mathrm{g}$ pUC19 for $0.3 \mathrm{mg} / \mathrm{mL}$ 2-pyrrolidinone coated needle shaped MNPs. The ferrimagnetic properties of the needle shaped nanoparticles may contribute for the formation of chestnut bur-shaped aggregates facilitating the adsorption and entrance of pUC19 into the cells [37,39]. Some aggregation of the needle shaped MNPs is likely to occur, forming penetration intermediates with the cells as the friction time increases and the moisture is absorbed into the Petri dishes. The observed positive genetic modification results are a consequence of the needle-like shape of the coated MNPs submitted to frictional stimulation and cannot be attributed to the effect of 2-pyrrolidinone itself. If 2-pyrrolidinone was by itself the cause, both types of 2-pyrrolidinone coated MNPs should have produced positive genetic modification results, but the 2-pyrrolidinone coated spherical shaped MNPs failed in producing transformed colonies. Moreover, despite the low cytotoxicity $\left(\mathrm{IC}_{50}\right.$ values of $2.5 \mu \mathrm{g} / \mathrm{ml}$ for HeLa cells and $3 \mu \mathrm{g} / \mathrm{ml}$ for PC-3 cells [70]) and the cationic nature of 2-pyrrolidinone, there is no evidence supporting any inherent transfection capabilities, which would require the formation in aqueous environment of stable DNA-2pyrrolidinone cationic complexes capable of translocating the cell envelope without detrimental cell death, which is unfavorable due to the high water solubility and low molecular weight of 2-pyrrolidinone.

The transformation efficiency obtained is not very high, however, each assay produced dozens of colonies (Fig. 3b) and the approach has potential to be used for cloning purposes [71] by an easy one-step procedure since the cells that were used are non-competent, which translates to a simpler, more cost-effective and less time-consuming process than conventional or improved heat-shock [72] or electroporation [73] approaches. The growth of blue colonies in the presence of ampicillin confirms that the pUC19 plasmid entered the cell and was translated. Transformation was successfully accomplished using this procedure, since the non-transformed host only produces white colonies and does not survive at the ampicillin concentration present in the Petri dishes. Considering that endocytosis is not performed by E. coli JM109, the form factor of the delivery agent should play an important role in transformation due the requirement of a cell envelope piercing mechanism, which should be promoted by nanoscale needle-like morphologies. In fact, sepiolite and $\mathrm{Mg}$ aminoclays, being the usual reported delivery agents capable of promoting transformation of microorganisms, also possess a high aspect ratio between two of their dimensions [74,75], which supports this hypothesis. Moreover, theoretical and experimental studies using high aspect ratio nanomaterials such as vertically aligned carbon nanotubes (CNTs) have suggested that the bending energy stored in the CNTs is a substantial factor for the physical rupture of both Gram-positive and Gram-negative bacteria [76]. Certain nanoparticles with high aspect ratio can also simultaneously facilitate the passive delivery of genetic material into species-independent plant cells and provide protection from nuclease degradation. Therefore, adjusting the aspect ratio of nanoparticles can also potentially contribute to the development of advanced plant biotechnology applications [77], in addition to any advantages that can be obtained from a likely increase in permeability of other types of eukaryotic cells, as well as become beneficial for further applications involving prokaryotes.

\subsubsection{Transformation of E. coli JM109 with pUC19 using magnetic stimulation}

No colonies were obtained in experiments with magnetic stimulation using the Magnefect-Nano II $^{\mathrm{TM}}$ bioreactor. The settings used corresponded to typical values used in magnetofection of eukaryotic cells, but possibly the intensity of the magnetic field produced by the device $(\sim 100 \mathrm{mT})$ is not high enough to induce permeation by the needle or spherical shaped MNPs across the cell envelope of $E$. coli JM109. Colonies never grew beyond the values observed in controls. Genetic modification using the Magnefect-Nano II $^{\mathrm{TM}}$ bioreactor might only be possible to attain if the cells are able to perform endocytosis of the delivery agent-DNA complex.

\section{Conclusions}

Water dispersible spherical and needle shaped 2-pyrrolidinone coated MNPs were produced and characterized by TEM, ATR-FTIR and SQUID. Both types of nanoparticles presented a magnetic behavior characteristic of magnetite nanoparticles consistent with their size, shape and coating layer. The saturation magnetization obtained at $300 \mathrm{~K}$ was $\mathrm{M}_{\mathrm{s}}=49$ and $\mathrm{M}_{\mathrm{s}}=30$ for spherical and needle shaped 2-pyrrolidinone coated MNPs respectively and the Verwey transition was detected in the MNPs with needle morphology. Transformation of E. coli JM109 was accomplished using monodisperse 2-pyrrolidinone coated needle shaped MNPs 

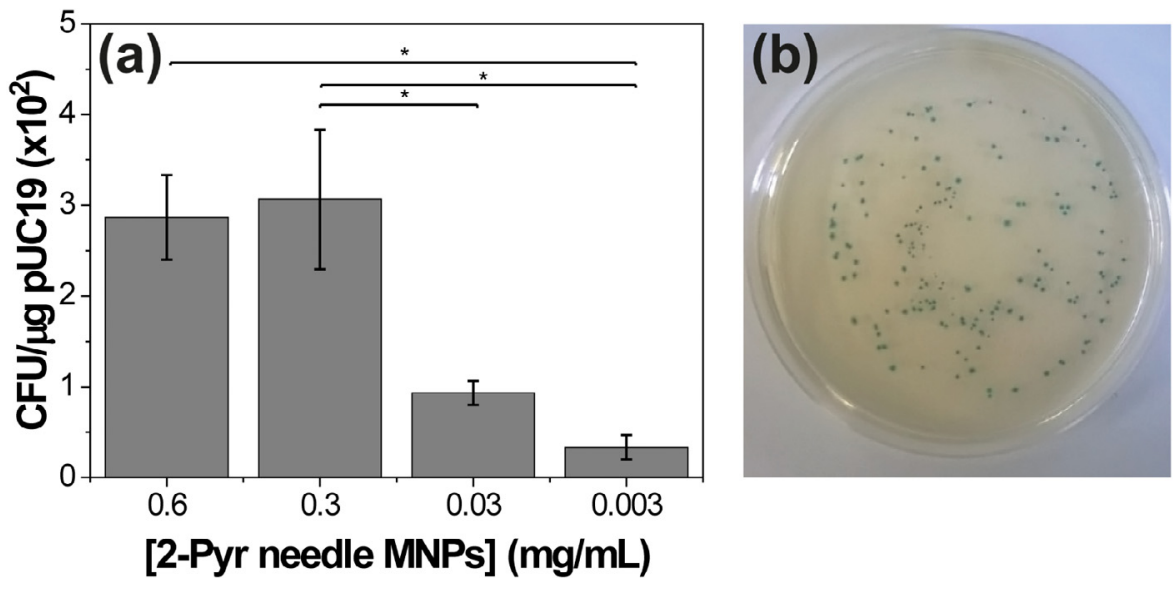

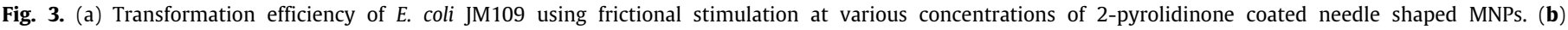
Representative image of a Petri dish of transformed E. coli JM109 colonies obtained using frictional stimulation with 2-pyrolidinone coated needle shaped MNPs.

through frictional stimulation, but magnetic stimulation using a commercial magnetofection bioreactor did not induce formation of transformed colonies. The maximum average transformation efficiency attained was $3.1 \times 10^{2} \mathrm{CFU} / \mu \mathrm{g}$ pUC19 for $0.3 \mathrm{mg} / \mathrm{mL}$ 2-pyrrolidinone coated needle shaped MNPs. The 2-pyrrolidinone coated spherical shaped MNPs are superparamagnetic at room temperature, a requirement to avoid aggregation into larger clustered structures, which could lead to more difficulties in cell envelope permeation. However, neither frictional nor magnetic stimulation produced transformants using these nanoparticles. This work suggests that the magnetic field produced by a standard bioreactor conceived for magnetofection of eukaryotic cells is not strong enough to enable the penetration of E. coli JM109 by any of the types of MNPs used. Moreover, the findings presented support the hypothesis that a high aspect ratio of the delivery agent is an important factor for the successful transformation through DNA delivery agents on E. coli JM109. The aspect ratio might also play an important role in the transformation of other prokaryotes, taking into account the difficulties for translocation of the cell wall compared to the eukaryotic cell membrane.

\section{CRediT authorship contribution statement}

G.P. Mendes: Study conception and design, Material preparation, Data collection, Analyzed the data, First draft of the manuscript was written, Commented on previous versions of the manuscript. L.D. Kluskens: Study conception and design, Analyzed the data, Commented on previous versions of the manuscript. M. Mota: Study conception and design, Analyzed the data, Contributed with new reagents and analytical tools, Commented on previous versions of the manuscript. S. LancerosMéndez: Study conception and design, Analyzed the data, Contributed with new reagents and analytical tools, Commented on previous versions of the manuscript. T. Alan Hatton: Study conception and design, Analyzed the data, Contributed with new reagents and analytical tools, Commented on previous versions of the manuscript.

\section{Declaration of competing interest}

The authors declare that they have no known competing financial interests or personal relationships that could have appeared to influence the work reported in this paper.

\section{Acknowledgments}

This work was supported by the Portuguese Foundation for Science and Technology (FCT) and the EU fund FEDER (Program COMPETE) under projects PTDC/AMB/68393/2006, PEstOE/EQB/LA0023/2013, UID/FIS/04650/2021, RECI/BBB-EBI/0179/ 2012 and the Project "BioEnv - Biotechnology and Bioengineering for a sustainable world". The authors also acknowledge FCT for the fellowship SFRH/BD/71661/2010 awarded to Gabriel Mendes under the scope of the MIT-Portugal Program, nanoTherics for providing the Magnefect-Nano II $^{\mathrm{TM}}$ device and Paul Brown for help in obtaining ATR-FTIR spectra. Finally, the authors acknowledge funding by the Spanish State Research Agency (AEI) through the project PID2019-106099RB-C43/AEI/10.13039/501100011033 and from the Basque Government Industry and Education Departments under the ELKARTEK and PIBA (PIBA-2018-06) programs, respectively. All authors have given approval to the final version of the manuscript.

\section{Appendix A. Supplementary data}

Supplementary material related to this article can be found online at https://doi.org/10.1016/j.nanoso.2021.100732.

\section{References}

[1] T.E.V. Aune, F.L. Aachmann, Methodologies to increase the transformation efficiencies and the range of bacteria that can be transformed, Appl. Microbiol. Biotechnol. 85 (2010) 1301-1313, http://dx.doi.org/10.1007/s00253009-2349-1.

[2] A.L. Rivera, D. Magaña Ortíz, M. Gómez-Lim, F. Fernández, A.M. Loske, Physical methods for genetic transformation of fungi and yeast, Phys. Life Rev. 11 (2014) 184-203, http://dx.doi.org/10.1016/j.plrev.2014.01.007.

[3] C. Plank, O. Zelphati, O. Mykhaylyk, Magnetically enhanced nucleic acid delivery. Ten years of magnetofection-Progress and prospects, Adv. Drug Deliv. Rev. 63 (2011) 1300-1331, http://dx.doi.org/10.1016/j.addr.2011.08. 002.

[4] C. Cen, J. Wu, Y. Zhang, C. Luo, L. Xie, X. Zhang, X. Yang, M. Li, Y. Bi, T. Li, T. $\mathrm{He}$, Improving magnetofection of magnetic polyethylenimine nanoparticles into MG-63 osteoblasts using a novel uniform magnetic field, Nanoscale Res. Lett. 14 (2019) 90, http://dx.doi.org/10.1186/s11671-019-2882-5.

[5] Y. Ma, Z. Zhang, X. Wang, W. Xia, H. Gu, Insights into the mechanism of magnetofection using MNPs-pei/pDNA/free PEI magnetofectins, Int. J. Pharm. 419 (2011) 247-254, http://dx.doi.org/10.1016/j.ijpharm.2011.07. 017.

[6] S. Huth, J. Lausier, S.W. Gersting, C. Rudolph, C. Plank, U. Welsch, J. Rosenecker, Insights into the mechanism of magnetofection using PEIbased magnetofectins for gene transfer, J. Gene Med. 6 (2004) 923-936, http://dx.doi.org/10.1002/jgm.577. 
[7] M. Zuvin, E. Kuruoglu, V.O. Kaya, O. Unal, O. Kutlu, H. Yagci Acar, D. Gozuacik, A. Kosar, Magnetofection of green fluorescent protein encoding DNA-bearing polyethyleneimine-coated superparamagnetic iron oxide nanoparticles to human breast cancer cells, ACS Omega 4 (2019) 12366-12374, http://dx.doi.org/10.1021/acsomega.9b01000.

[8] D. Ang, Q.V. Nguyen, S. Kayal, P.R. Preiser, R.S. Rawat, R.V. Ramanujan, Insights into the mechanism of magnetic particle assisted gene delivery, Acta Biomater. 7 (2011) 1319-1326, http://dx.doi.org/10.1016/j.actbio.2010.09. 037.

[9] A. Jermy, Bacterial endocytosis uncovered, Nat. Rev. Microbiol. 8 (2010) 534-535, http://dx.doi.org/10.1038/nrmicro2408.

[10] T.G.A. Lonhienne, E. Sagulenko, R.I. Webb, K.C. Lee, J. Franke, D.P. Devos, A. Nouwens, B.J. Carroll, J.A. Fuerst, Endocytosis-like protein uptake in the bacterium Gemmata obscuriglobus, Proc. Natl. Acad. Sci. USA 107 (2010) 12883-12888, http://dx.doi.org/10.1073/pnas.1001085107.

[11] F.A. Castro-Smirnov, O. Piétrement, P. Aranda, E. Le Cam, E. Ruiz-Hitzky, B.S. Lopez, Biotechnological applications of the sepiolite interactions with bacteria: Bacterial transformation and DNA extraction, Appl. Clay Sci. 191 (2020) 105613, http://dx.doi.org/10.1016/j.clay.2020.105613.

[12] L.F. Brito, M. Irla, T. Walter, V.F. Wendisch, Magnesium aminoclay-based transformation of Paenibacillus riograndensis and Paenibacillus polymyxa and development of tools for gene expression, Appl. Microbiol. Biotechnol. 101 (2017) 735-747, http://dx.doi.org/10.1007/s00253-016-7999-1.

[13] S. Kim, Y.-C. Lee, D.-H. Cho, H.U. Lee, Y.S. Huh, G.-J. Kim, H.-S. Kim, A simple and non-invasive method for nuclear transformation of intactwalled Chlamydomonas reinhardtii, PLoS One 9 (2014) e101018, http://dx. doi.org/10.1371/journal.pone.0101018.

[14] H.A. Choi, Y.C. Lee, J.Y. Lee, H.J. Shin, H.K. Han, G.J. Kim, A simple bacterial transformation method using magnesium- and calcium-aminoclays, J. Microbiol. Methods. 95 (2013) 97-101, http://dx.doi.org/10.1016/j.mimet. 2013.07.018.

[15] K. Modaresifar, S. Azizian, M. Ganjian, L.E. Fratila-Apachitei, A.A. Zadpoor, Bactericidal effects of nanopatterns: A systematic review, Acta Biomater. 83 (2019) 29-36, http://dx.doi.org/10.1016/j.actbio.2018.09.059.

[16] E.P. Ivanova, D.P. Linklater, M. Werner, V.A. Baulin, X.M. Xu, N. Vrancken, S. Rubanov, E. Hanssen, J. Wandiyanto, V.K. Truong, A. Elbourne, S. Maclaughlin, S. Juodkazis, R.J. Crawford, The multi-faceted mechano-bactericidal mechanism of nanostructured surfaces, Proc. Natl. Acad. Sci. USA 117 (2020) 12598-12605, http://dx.doi.org/10.1073/pnas.1916680117.

[17] D.P. Linklater, V.A. Baulin, S. Juodkazis, R.J. Crawford, P. Stoodley, E.P. Ivanova, Mechano-bactericidal actions of nanostructured surfaces, Nat. Rev. Microbiol. 19 (2021) 8-22, http://dx.doi.org/10.1038/s41579-020-0414-z.

[18] D. Şen Karaman, S. Sarwar, D. Desai, E.M. Björk, M. Odén, P. Chakrabarti, J.M. Rosenholm, S. Chakraborti, Shape engineering boosts antibacterial activity of chitosan coated mesoporous silica nanoparticle doped with silver: A mechanistic investigation, J. Mater. Chem. B. 4 (2016) 3292-3304, http://dx.doi.org/10.1039/c5tb02526e.

[19] D. Acharya, K.M. Singha, P. Pandey, B. Mohanta, J. Rajkumari, L.P. Singha, Shape dependent physical mutilation and lethal effects of silver nanoparticles on bacteria, Sci. Rep. 8 (2018) 201, http://dx.doi.org/10.1038/s41598017-18590-6.

[20] J. Penders, M. Stolzoff, D.J. Hickey, M. Andersson, T.J. Webster, Shapedependent antibacterial effects of non-cytotoxic gold nanoparticles, Int. J. Nanomed. 12 (2017) 2457-2468, http://dx.doi.org/10.2147/IJN.S124442.

[21] M. Sheikholeslami, S.A. Farshad, Z. Ebrahimpour, Z. Said, Recent progress on flat plate solar collectors and photovoltaic systems in the presence of nanofluid: A review, J. Clean. Prod. 293 (2021) 126119, http://dx.doi.org/ 10.1016/j.jclepro.2021.126119.

[22] X. Ye, S.G. Kandlikar, C. Li, Viscosity of nanofluids containing anisotropic particles: A critical review and a comprehensive model, Eur. Phys. J. E. 42 (2019) 1-34, http://dx.doi.org/10.1140/epje/i2019-11923-7.

[23] M. Sheikholeslami, M. Jafaryar, Z. Said, A.I. Alsabery, H. Babazadeh, A. Shafee, Modification for helical turbulator to augment heat transfer behavior of nanomaterial via numerical approach, Appl. Therm. Eng. 182 (2021) 115935, http://dx.doi.org/10.1016/j.applthermaleng.2020.115935.

[24] M. Sheikholeslami, S.A. Farshad, Z. Said, Analyzing entropy and thermal behavior of nanomaterial through solar collector involving new tapes, Int. Commun. Heat Mass Transf. 123 (2021) 105190, http://dx.doi.org/10.1016/ j.icheatmasstransfer.2021.105190.

[25] M.S. Beg, J. Mohapatra, L. Pradhan, D. Patkar, D. Bahadur, Porous $\mathrm{Fe}_{3} \mathrm{O}_{4}-$ $\mathrm{SiO}_{2}$ core-shell nanorods as high-performance MRI contrast agent and drug delivery vehicle, J. Magn. Magn. Mater. 428 (2017) 340-347, http: //dx.doi.org/10.1016/j.jmmm.2016.12.079.

[26] Z. Zhou, X. Zhu, D. Wu, Q. Chen, D. Huang, C. Sun, J. Xin, K. Ni, J. Gao, Anisotropic shaped iron oxide nanostructures: Controlled synthesis and proton relaxation shortening effects, Chem. Mater. 27 (2015) 3505-3515, http://dx.doi.org/10.1021/acs.chemmater.5b00944.
[27] Z.-G. Yue, W. Wei, Z.-X. You, Q.-Z. Yang, H. Yue, Z.-G. Su, G.-H. Ma, Iron oxide nanotubes for magnetically guided delivery and $\mathrm{pH}$-activated release of insoluble anticancer drugs, Adv. Funct. Mater. 21 (2011) 3446-3453, http://dx.doi.org/10.1002/adfm.201100510.

[28] P. Yu, X.M. Xia, M. Wu, C. Cui, Y. Zhang, L. Liu, B. Wu, C.X. Wang, L.J. Zhang, X. Zhou, R.X. Zhuo, S.W. Huang, Folic acid-conjugated iron oxide porous nanorods loaded with doxorubicin for targeted drug delivery, Colloids Surf. B 120 (2014) 142-151, http://dx.doi.org/10.1016/j.colsurfb.2014.05.018.

[29] D. Niculaes, A. Lak, G.C. Anyfantis, S. Marras, O. Laslett, S.K. Avugadda, M. Cassani, D. Serantes, O. Hovorka, R. Chantrell, T. Pellegrino, Asymmetric assembling of iron oxide nanocubes for improving magnetic hyperthermia performance, ACS Nano. 11 (2017) 12121-12133, http://dx.doi.org/10. 1021/acsnano.7b05182.

[30] R. Das, J. Alonso, Z. Nemati Porshokouh, V. Kalappattil, D. Torres, M.H. Phan, E. Garaio, J.Á. García, J.L. Sanchez Llamazares, H. Srikanth, Tunable high aspect ratio iron oxide nanorods for enhanced hyperthermia, J. Phys. Chem. C. 120 (2016) 10086-10093, http://dx.doi.org/10.1021/acs.jpcc.6b02006.

[31] J.Y. Chen, Y.L. Liao, T.H. Wang, W.C. Lee, Transformation of Escherichia coli mediated by magnetic nanoparticles in pulsed magnetic field, Enzyme Microb. Technol. 39 (2006) 366-370, http://dx.doi.org/10.1016/j.enzmictec. 2005.11.035.

[32] J. Rodríguez-Beltrán, H. Elabed, K. Gaddour, J. Blázquez, A. Rodríguez-Rojas, Simple DNA transformation in Pseudomonas based on the Yoshida effect, J. Microbiol. Methods. 89 (2012) 95-98, http://dx.doi.org/10.1016/j.mimet. 2012.02 .013$.

[33] G. Wilharm, D. Lepka, F. Faber, J. Hofmann, T. Kerrinnes, E. Skiebe, A simple and rapid method of bacterial transformation, J. Microbiol. Methods. 80 (2010) 215-216, http://dx.doi.org/10.1016/j.mimet.2009.12.002.

[34] G.P. Mendes, P.S. Vieira, S. Lanceros-Méndez, L.D. Kluskens, M. Mota, Transformation of Escherichia coli JM109 using pUC19 by the Yoshida effect, J. Microbiol. Methods. 115 (2015) 1-5, http://dx.doi.org/10.1016/j.mimet. 2015.05.012.

[35] H. Elabed, R. Hamza, A. Bakhrouf, K. Gaddour, Rapid DNA transformation in Salmonella Typhimurium by the hydrogel exposure method, J. Microbiol. Methods. 126 (2016) 67-71, http://dx.doi.org/10.1016/j.mimet.2016. 04.017.

[36] N. Yoshida, K. Kodama, K. Nakata, M. Yamashita, T. Miwa, Escherichia coli cells penetrated by chrysotile fibers are transformed to antibiotic resistance by incorporation of exogenous plasmid DNA, Appl. Microbiol. Biotechnol. 60 (2002) 461-468, http://dx.doi.org/10.1007/s00253002-1148-8.

[37] N. Yoshida, Y. Saeki, Chestnut bur-shaped aggregates of chrysotile particles enable inoculation of Escherichia coli cells with plasmid DNA, Appl. Microbiol. Biotechnol. 65 (2004) 566-575, http://dx.doi.org/10.1007/s00253004-1649-8.

[38] N. Yoshida, T. Ikeda, T. Yoshida, T. Sengoku, K. Ogawa, Chrysotile asbestos fibers mediate transformation of Escherichia coli by exogenous plasmid DNA, FEMS Microbiol. Lett. 195 (2001) 133-137, http://dx.doi.org/10.1111/ j.1574-6968.2001.tb10510.x.

[39] N. Yoshida, K. Ide, Plasmid DNA is released from nanosized acicular material surface by low molecular weight oligonucleotides: Exogenous plasmid acquisition mechanism for penetration intermediates based on the yoshida effect, Appl. Microbiol. Biotechnol. 80 (2008) 813-821, http: //dx.doi.org/10.1007/s00253-008-1637-5.

[40] N. Yoshida, T. Naka, K. Ohta, Mutagenesis of bacteria by fibrous or clay minerals, J. Biol. Sci. 4 (2004) 532-536, http://dx.doi.org/10.3923/jbs.2004. 532.536.

[41] N. Yoshida, M. Sato, Plasmid uptake by bacteria: A comparison of methods and efficiencies, Appl. Microbiol. Biotechnol. 83 (2009) 791-798, http: //dx.doi.org/10.1007/s00253-009-2042-4.

[42] Z. Li, H. Chen, H. Bao, M. Gao, One-pot reaction to synthesize watersoluble magnetite nanocrystals, Chem. Mater. 16 (2004) 1391-1393, http: //dx.doi.org/10.1021/cm035346y.

[43] H. Sun, B. Chen, X. Jiao, Z. Jiang, Z. Qin, D. Chen, Solvothermal synthesis of tunable electroactive magnetite nanorods by controlling the side reaction, J. Phys. Chem. C. 116 (2012) 5476-5481, http://dx.doi.org/10.1021/ jp211986a.

[44] M. Lattuada, T.A. Hatton, Functionalization of monodisperse magnetic nanoparticles, Langmuir 23 (2007) 2158-2168, http://dx.doi.org/10.1021/ la062092x.

[45] A. Fouriki, J. Dobson, Oscillating magnet array-based nanomagnetic gene transfection of human mesenchymal stem cells, Nanomedicine 9 (2014) 989-997, http://dx.doi.org/10.2217/nnm.13.74.

[46] A. Fouriki, N. Farrow, M.A. Clements, J. Dobson, Evaluation of the magnetic field requirements for nanomagnetic gene transfection, Nano Rev. 1 (2010) 5167, http://dx.doi.org/10.3402/nano.v1i0.5167.

[47] J.M. Kinsella, A. Ivanisevic, Enzymatic clipping of DNA wires coated with magnetic nanoparticles, J. Am. Chem. Soc. 127 (2005) 3276-3277, http: //dx.doi.org/10.1021/ja043865b. 
[48] D.M.L. Goodgame, D.J. Williams, R.E.P. Winpenny, Novel bimetallic macrocyclic polymer structures incorporating deprotonated 2-pyrrolidone bridges: The crystal structures of $\left[\left\{\mathrm{Hg}_{2} \mathrm{Cu}\left(\mathrm{C}_{4} \mathrm{H}_{6} \mathrm{NO}\right)_{4}\right\} \mathrm{X}_{2}\right]_{\mathrm{n}}\left(\mathrm{X} \mathrm{NO}_{3}\right.$ or $\left.\mathrm{ClO}_{4}\right)$, Angew. Chemie Int. Ed. English. 26 (1987) 1044-1045, http://dx.doi.org/ 10.1002/anie. 198710441.

[49] J.M. Kinsella, A. Ivanisevic, DNA-templated magnetic nanowires with different compositions: Fabrication and analysis, Langmuir 23 (2007) 3886-3890, http://dx.doi.org/10.1021/la0628571.

[50] Y.S. Li, J.S. Church, A.L. Woodhead, Infrared and Raman spectroscopic studies on iron oxide magnetic nano-particles and their surface modifications, J. Magn. Magn. Mater. 324 (2012) 1543-1550, http://dx.doi.org/10.1016/j. jmmm.2011.11.065.

[51] N.A. Frey, S. Peng, K. Cheng, S. Sun, Magnetic nanoparticles: Synthesis, functionalization, and applications in bioimaging and magnetic energy storage, Chem. Soc. Rev. 38 (2009) 2532, http://dx.doi.org/10.1039/ b815548h.

[52] Arora Wahajuddin, Superparamagnetic iron oxide nanoparticles: magnetic nanoplatforms as drug carriers, Int. J. Nanomed. 7 (2012) 3445, http: //dx.doi.org/10.2147/IJN.S30320.

[53] K. Abdulwahab, M.A. Malik, P. O’Brien, K. Govender, C.A. Muryn, G.A. Timco, F. Tuna, R.E.P. Winpenny, Synthesis of monodispersed magnetite nanoparticles from iron pivalate clusters, Dalt. Trans. 42 (2013) 196-206, http://dx.doi.org/10.1039/c2dt32478d.

[54] P.T. Phong, V.T.K. Oanh, T.D. Lam, N.X. Phuc, L.D. Tung, N.T.K. Thanh, D.H. Manh, Iron oxide nanoparticles: Tunable size synthesis and analysis in terms of the core-shell structure and mixed coercive model, J. Electron. Mater. 46 (2017) 2533-2539, http://dx.doi.org/10.1007/s11664-017-53378.

[55] J. Wang, Q. Chen, C. Zeng, B. Hou, Magnetic-field-induced growth of single-crystalline $\mathrm{Fe}_{3} \mathrm{O}_{4}$ nanowires, Adv. Mater. 16 (2004) 137-140, http: //dx.doi.org/10.1002/adma.200306136.

[56] J. Wang, Y. Wu, Y. Zhu, Fabrication of complex of $\mathrm{Fe}_{3} \mathrm{O}_{4}$ nanorods by magnetic-field-assisted solvothermal process, Mater. Chem. Phys. 106 (2007) 1-4, http://dx.doi.org/10.1016/j.matchemphys.2007.04.061.

[57] J. Park, E. Lee, N.-M. Hwang, M. Kang, S.C. Kim, Y. Hwang, J.-G. Park, H.-J. Noh, J.-Y. Kim, J.-H. Park, T. Hyeon, One-nanometer-scale sizecontrolled synthesis of monodisperse magnetic iron oxide nanoparticles, Angew. Chemie Int. Ed. 44 (2005) 2872-2877, http://dx.doi.org/10.1002/ anie.200461665.

[58] Z. Li, B. Tan, M. Allix, A.I. Cooper, M.J. Rosseinsky, Direct coprecipitation route to monodisperse dual-functionalized magnetic iron oxide nanocrystals without size selection, Small 4 (2008) 231-239, http://dx.doi.org/10. 1002/smll.200700575.

[59] R.M. Cornell, U. Schwertmann, The Iron Oxides, second ed., Wiley, Weinheim, FRG, 2003, http://dx.doi.org/10.1002/3527602097.

[60] Q. Yu, A. Mottaghizadeh, H. Wang, C. Ulysse, A. Zimmers, V. Rebuttini, N. Pinna, H. Aubin, Verwey transition in single magnetite nanoparticles, Phys. Rev. B 90 (2014) 075122, http://dx.doi.org/10.1103/PhysRevB.90.075122.

[61] L.R. Bickford, The low temperature transformation in ferrites, Rev. Modern Phys. 25 (1953) 75-79, http://dx.doi.org/10.1103/RevModPhys.25.75.

[62] G.F. Goya, T.S. Berquó, F.C. Fonseca, M.P. Morales, Static and dynamic magnetic properties of spherical magnetite nanoparticles, J. Appl. Phys. 94 (2003) 3520-3528, http://dx.doi.org/10.1063/1.1599959.

[63] A. Mitra, J. Mohapatra, S.S. Meena, C.V. Tomy, M. Aslam, Verwey transition in ultrasmall-sized octahedral $\mathrm{Fe}_{3} \mathrm{O}_{4}$ nanoparticles, J. Phys. Chem. C 118 (2014) 19356-19362, http://dx.doi.org/10.1021/jp501652e.
[64] M. Bohra, N. Agarwal, V. Singh, A short review on Verwey transition in nanostructured $\mathrm{Fe}_{3} \mathrm{O}_{4}$ materials, J. Nanomater. 2019 (2019) 1-18, http: //dx.doi.org/10.1155/2019/8457383.

[65] F.X. Redl, C.T. Black, G.C. Papaefthymiou, R.L. Sandstrom, M. Yin, H. Zeng, C.B. Murray, S.P. O’Brien, Magnetic, electronic, and structural characterization of nonstoichiometric iron oxides at the nanoscale, J. Am. Chem. Soc. 126 (2004) 14583-14599, http://dx.doi.org/10.1021/ja046808r.

[66] S. Chandra, R. Das, V. Kalappattil, T. Eggers, C. Harnagea, R. Nechache, M.H. Phan, F. Rosei, H. Srikanth, Epitaxial magnetite nanorods with enhanced room temperature magnetic anisotropy, Nanoscale 9 (2017) 7858-7867, http://dx.doi.org/10.1039/c7nr01541k.

[67] Q. Han, Z. Liu, Y. Xu, H. Zhang, Synthesis and magnetic properties of singlecrystalline magnetite nanowires, J. Cryst. Growth. 307 (2007) 483-489, http://dx.doi.org/10.1016/j.jcrysgro.2007.07.020.

[68] F. Walz, The Verwey transition-A topical review, J. Phys. Condens. Matter. 14 (2002) R285-R340, http://dx.doi.org/10.1088/0953-8984/14/12/203.

[69] R. Prozorov, T. Prozorov, S.K. Mallapragada, B. Narasimhan, T.J. Williams, D.A. Bazylinski, Magnetic irreversibility and the Verwey transition in nanocrystalline bacterial magnetite, Phys. Rev. B. 76 (2007) 054406, http: //dx.doi.org/10.1103/PhysRevB.76.054406.

[70] R. Thangam, V. Suresh, M. Rajkumar, J.D. Vincent, P. Gunasekaran, C. Anbazhagan, K. Kaveri, S. Kannan, Antioxidant and in vitro anticancer effect of 2-pyrrolidinone rich fraction of Brassica oleracea var. capitata through induction of apoptosis in human cancer cells, Phyther. Res. 27 (2013) 1664-1670, http://dx.doi.org/10.1002/ptr.4908.

[71] J. Ren, S. Karna, H.-M. Lee, S.M. Yoo, D. Na, Artificial transformation methodologies for improving the efficiency of plasmid DNA transformation and simplifying its use, Appl. Microbiol. Biotechnol. 103 (2019) 9205-9215, http://dx.doi.org/10.1007/s00253-019-10173-x.

[72] W.T. Chan, C.S. Verma, D.P. Lane, S.K.E. Gan, A comparison and optimization of methods and factors affecting the transformation of Escherichia coli, Biosci. Rep. 33 (2013) 86, http://dx.doi.org/10.1042/BSR20130098.

[73] M.J. Park, M.S. Park, G.E. Ji, Improvement of electroporation-mediated transformation efficiency for a Bifidobacterium strain to a reproducibly high level, J. Microbiol. Methods. 159 (2019) 112-119, http://dx.doi.org/10.1016/ j.mimet.2018.11.019.

[74] G.P. Mendes, L.D. Kluskens, S. Lanceros-Méndez, M. Mota, Magnesium aminoclays as plasmid delivery agents for non-competent Escherichia coli JM109 transformation, Appl. Clay Sci. 204 (2021) 106010, http://dx.doi.org/ 10.1016/j.clay.2021.106010.

[75] M. Suárez, E. García-Romero, Variability of the surface properties of sepiolite, Appl. Clay Sci. 67-68 (2012) 72-82, http://dx.doi.org/10.1016/ j.clay.2012.06.003.

[76] D.P. Linklater, M. De Volder, V.A. Baulin, M. Werner, S. Jessl, M. Golozar, L. Maggini, S. Rubanov, E. Hanssen, S. Juodkazis, E.P. Ivanova, High aspect ratio nanostructures kill bacteria via storage and release of mechanical energy, ACS Nano. 12 (2018) 6657-6667, http://dx.doi.org/10.1021/acsnano. 8b01665.

[77] G.S. Demirer, H. Zhang, J.L. Matos, N.S. Goh, F.J. Cunningham, Y. Sung, R. Chang, A.J. Aditham, L. Chio, M.J. Cho, B. Staskawicz, M.P. Landry, High aspect ratio nanomaterials enable delivery of functional genetic material without DNA integration in mature plants, Nat. Nanotechnol. 14 (2019) 456-464, http://dx.doi.org/10.1038/s41565-019-0382-5. 